

\title{
The Principles of Cooperative Learning in an Oral Communication Course in English: A Descriptive Analysis
}

\author{
Juan Pablo Zúñiga Vargas ${ }^{1}$ \\ Universidad de Costa Rica \\ San José, Costa Rica \\ juanpablo.zunigavargas@ucr.ac.cr
}

\begin{abstract}
This article reports on the findings of a research conducted to describe the occurrence and effect of the principles of Cooperative Learning in an oral communication course in English for sophomores during one semester at a public university in Costa Rica. To collect data for the study, three instruments were used, an interview for the professor of the group, a questionnaire for the students, and class observations. The data collected were triangulated by means of predetermined categories of analysis. Overall, the findings obtained indicate that the use of Cooperative Learning, in addition to the professor's commitment to support her students to learn, has produced significant results.
\end{abstract}

Keywords: Cooperative Learning, positive interdependence, individual and group accountability, promotive

\section{(ब) $\Theta \Theta$}

Recibido: 20 de enero de 2015 - Aprobado: 18 de agosto de 2015

1 Profesor de inglés para otras carreras, Universidad de Costa Rica. Profesor de pedagogía e investigación educativa para la enseñanza del inglés, Universidad Nacional, Costa Rica. Magíster en la Enseñanza del Inglés como Lengua Extranjera y Bachiller en Inglés, ambos títulos obtenidos en la Universidad de Costa Rica. 
interaction, interpersonal and small group skills, group processing

\section{Resumen}

Este artículo reporta los resultados de una investigación realizada con el fin de describir la incidencia y efecto de los principios del Aprendizaje Cooperativo en un curso de comunicación oral en inglés de segundo año durante un semestre en una universidad pública en Costa Rica. Para recolectar información para el estudio, se utilizaron tres instrumentos, una entrevista para el profesor del grupo, un cuestionario para los estudiantes y observaciones de clase. Los datos recolectados se triangularon por medio de categorías de análisis predeterminadas por el investigador. En general, los resultados obtenidos indican que el uso del aprendizaje cooperativo, junto con el compromiso de la profesora para apoyar a sus estudiantes para aprender, ha producido resultados significativos.

Palabras clave: Aprendizaje Cooperativo, interdependencia positiva, responsabilidad individual y grupal, interacción promovida, destrezas interpersonales y de grupos pequeños, procesamiento grupal

\section{Introduction}

The concept of Cooperative Learning (CL) essentially refers to the pedagogical use of group work activities to encourage students to work collectively to increase their own and one another's learning (Johnson, Johnson, \& Holubec, 2008). Historically speaking, the first study on CL was published in 1898, and since then, hundreds of studies on CL have been conducted (Johnson, Johnson, \& Holubec, 2008), yet Cooperative Learning continues to be valid nowadays. In fact, when used appropriately, Cooperative Learning may prove a very valuable tool for many teachers. For the same reason, this research has been conducted hoping that its results can be of help or reference to in-service and pre-service teachers who are unfamiliar with CL but would like to try it in their classrooms.

Although numerous studies on CL have been carried out, many of them deal with the effects of CL on students' performance in the 
class and the connection of CL with the students' performance in a given linguistic skill in the language classroom specifically (Farzaneh, \& Nejadansari, 2014; Mahmoud, 2014; Zhang, 2012; Zhang, 2010); a few other studies deal with how CL may affect teacher performance (Dikici \& Yavuzer, 2006) or student ratings of their cooperative learning work (Kaufman, Felder, \& Fuller, 2000). Thus, this research study aimed at analyzing the occurrence of the principles of Cooperative Learning per se and their effect on student learning in an oral communication course for sophomores at a public Costa Rican University.

\section{Defining Cooperative Learning}

Cooperative Learning (CL) refers to the use of group work to serve pedagogical purposes (Johnson, Johnson, \& Holubec, 2008). The aim of this educational approach is to increase each student's performance and learning by working together with other classmates (Leon \& Tai, 2004). In this sense, cooperative learning activities might be considered better than other kinds of classwork in the sense that CL does not require students to compete with one another, which may be described as a rather negative facet of Costa Rican culture taking into account the specific context of the research conducted. Instead, in Cooperative Learning, students work together to accomplish common tasks with more beneficial results, such as an individual and a communal sense of achievement. Compared to individualistic efforts, Cooperative Learning offers the possibility of minimizing the problem of having students left behind since CL motivates students to encourage each other to work more effectively (Summers, Beretvas, Sviniki, \& Gorin, 2005).

Aside from this, Cooperative Learning is different form other types of group work, for it does not simply imply assigning students to groups and expect that they will work appropriately. For instance, in pseudo-learning groups and traditional classroom learning groups (Johnson, Johnson, \& Holubec, 2008), students are just placed together in groups in which they will compete with one another and will be evaluated individually. Conversely, in a Cooperative Learning group, students must understand both that they are not in a competition and that the failure of one of the group members means the failure of the whole group. 


\section{Making Cooperative Learning Work}

As said previously, Cooperative Learning is not simply having students work in groups. Therefore, assuming that students will work correctly by virtue of the fact that they are in groups is a misinterpretation of CL (Schulte, 1999). What is more, many students do not know how to work in groups cooperatively (Johnson, Johnson, \& Smith, 1998). Students who have never worked in CL groups before need to be taught the necessary social skills to interact with each other satisfactorily (Goodwin, 1999). For instance, before using CL in a course, a teacher could use introduction activities for his or her students to know each other or activities in which students need to take turns and perform individual and group tasks in order for the students to see the value of individual and collective efforts. This will produce a better classroom atmosphere and thus more academic gains (Hernández, 2003; Summers, Beretvas, Sviniki, \& Gorin, 2005).

No one has said that implementing Cooperative Learning in the classroom is an easy task. There will be times in which a CL teacher feels discouraged because the development of his or her class will seem to go in the wrong direction. However, the key to using CL is careful lesson planning, diligence, and perseverance. After some time doing this, the positive effects of Cooperative Learning will become visible (Jensen, Moore, \& Hatch, 2004; Jacobs \& Hall, 1994; Schulte, 1999). In this regard, beginning with pair work in the early stages of implementing CL is advisable since this gives more control over the class. After that, bigger groups can be used (Hernández, 2003). In connection with grouping students in CL, Johnson and Johnson (2014) described informal and formal cooperative learning groups. Informal CL groupings can be used temporarily during one to several lessons for the students to build necessary cooperative skills, while formal CL groupings can be used throughout a whole term to build a community of collaboration among students.

\section{Analyzing the Principles of Cooperative Learning}

For an appropriate implementation of CL, the main proponents of this educational approach, have articulated five essential principles for it, namely, a) Positive Interdependence, b) Individual and Group 
Accountability, c) Promotive Interaction, d) Interpersonal and Small Group Skills, and e) Group Processing (Johnson, Johnson, \& Holubec, 2008; Johnson, Johnson, \& Smith, 2007). Each principle will be briefly described in turn.

\section{a) Positive Interdependence}

This concept, in essence, refers to the idea that all the students in a group must understand what they need to do in any given activity and that they need to depend on each other to do it: Either all of them will succeed, or they will not.

\section{b) Individual and Group Accountability}

The ultimate aim of CL is to make each group member a better student. To do this, the group as a whole must have a clear idea what is expected from their individual and group work; there are individual and collective responsibilities. As well, each group member needs to know that his or her performance is going to be assessed by the other group members.

\section{c) Promotive Interaction}

Students must know that they are working cooperatively and collaboratively, so the teacher's responsibility is to allow them to be aware that they must help, support, and encourage one another.

\section{d) Interpersonal and Small Group Skills}

In this principle, social skills play a fundamental role. Students should learn how to work as a group, how to deal with discrepancies, and how to negotiate with each other in order to make decisions that benefit the whole group.

\section{e) Group Processing}

At the end of a CL activity, the teacher should have students assess the work that they just did so that they can identify what problems they had while working and come up with ways to solve and minimize them in future activities. 


\section{Considering the Implications of Implementing CL in a Foreign Language Classroom}

Learning a foreign language should be a dynamic process, so lecturing students may not be very practical in this sense. In addition, a foreign language teacher many times faces the challenge of having to manage oversized groups of students, a situation which in itself limits students' chance of practicing their foreign language (Hernández, 2003). Therefore, using Cooperative Learning can be a good option to deal with this situation. In a foreign language classroom, students need to practice and review what they are learning, and this may seldom occur if traditional language teaching methods are used.

Other influential aspects in a foreign language learning process are school alienation, the fear of making mistakes, and the students' being intimidated by the teacher. When Cooperative Learning activities are used in the class, students have the opportunity to build relationships among themselves, boost their self-esteem, and even overcome their learning fears. As a consequence, students' attendance might become more consistent, and they may reduce their feeling of isolation in school (Ghaith, 2003; Johnson, Johnson, \& Smith, 1998). Solving these problems is crucial in learning and teaching a foreign language, and this is precisely what CL may help to do.

\section{Methodology}

\section{Type of Study}

As this study dealt with the occurrence of the principles of Cooperative Learning in an oral communication course in English, the researcher opted for carrying out a descriptive study which, according to Hernández, Fernández, and Baptista (2006, p. 99), seeks to describe how phenomena, situations, contexts, and events manifest themselves.

\section{Context and Participants}

This research study was conducted at a public university in Costa Rica in an oral communication course in English during one semester. The procedure for choosing the participants of the study was a convenience one. In order to find both the right group and the right professor to carry out the research, the researcher proceeded to ask for the counsel 
of another professor from the university, and this enquiry led him to the chosen group and professor. The professor in question had many years' teaching experience, specifically at least 20 years' experience working with CL. Her oral communication course had 25 sophomore students including both males and females between ages 19 and 25, with the exception of a 43-year-old man.

\section{Instruments}

To collect information for the research project carried out, three different data collection were used. Each of them will be described below:

\section{Interview}

A structured interview (See Appendix A) for the professor of the observed group was designed. It consisted of nine questions dealing with the professor's experience using CL, general characteristics of CL, recommendations for using $\mathrm{CL}$, and the pros and cons of using $\mathrm{CL}$.

\section{Questionnaire}

A questionnaire for the students was designed (See Appendix B). It included twelve closed questions dealing with the students' prior experience with group work and cooperative activities, one or more questions related to the five principles of Cooperative Learning proposed by Johnson, Johnson, and Holubec (2008), and two questions dealing with the students' opinion about their experience with CL.

\section{Observation}

The researcher attended the surveyed group of students at least once a week during one semester and took field notes (Richards \& Farrell, 2005) of any outstanding moments in the lessons which could be related to the principles of Cooperative Learning.

\section{Data Analysis}

The data collected were analyzed by means of triangulation. Information coming from the different data collection instruments was extracted and classified using predetermined categories of analysis. The first category used was "Students' Prior Experience with Group Work or Cooperative Activities" to establish a background for the analysis of data. The five principles of Cooperative Learning (i.e., Positive 
Interdependence, Individual and Group Accountability, Promotive Interaction, Interpersonal and Small Group Skills, and Group Processing) proposed by Johnson, Johnson, and Holubec (2008) were also used as categories of analysis. The last category of analysis used was "Students' Assessment of their Experience with Cooperative Learning." Additionally, the answers given by the students in the questionnaire were tallied, and percentages were obtained for each of the choices made by the students in this instrument.

\section{Procedures}

The first step taken to conduct the research project was to find a professor that was currently using Cooperative Learning in one of his or her university courses. After this participant was found, official permission to conduct a research project in her group was requested in writing. Then, both the researcher and the professor agreed on a suitable time and date to conduct the interview. The interview was conducted in the professor's office in private and in a rather casual way to make her feel at ease and obtain reliable answers from her. After this, the researcher attended her oral communication course at least once a week during the semester for her students to become accustomed to his presence and prevent any possible disruptions in the students' behavior in class. Finally, the questionnaire was administered towards the middle of the semester before the class started in order to avoid having the students give hasty answers if the instrument had been administered at the end of the class and to obtain more reliable responses from them.

\section{Results and Discussion}

\section{Students' Prior Experience with Group Work or Cooperative Activities}

\section{Table 1. Background for the Study}

\begin{tabular}{|l|c|c|}
\cline { 3 - 3 } \multicolumn{2}{l|}{} & Percentage \\
\hline Q1. Students who had done similar activities before: & YES: & $81.25 \%$ \\
& NO: & $18.75 \%$ \\
\hline Q2. Students who said they liked working in groups: & YES: & $81.25 \%$ \\
& NO: & $18.75 \%$ \\
\hline
\end{tabular}

Note: Information collected with the questionnaire (See Appendix B) 
As seen in Table 1, the majority of the students surveyed had had previous experience with group work and can be said to be receptive to it even though they may not have been acquainted with CL. In the studied group, this may be regarded as a positive factor since the professor could have taken advantage of this to focus on the necessary skills for the students to really work in a cooperative fashion when arranged in groups. Indeed, while conducting the observations, the researcher could notice that the professor assigned different roles to the students when they worked in groups. These included roles such as time keeper, leader, and language monitor, whose purpose the students understood well in the development of the group activities.

It is curious also to note that the $18.75 \%$ of the students who said they do not like working in groups were male. In this regard, this may be consistent with the information obtained in the research conducted by Summers, Beretvas, Sviniki, and Gorin (1995), who found that women appear to like group work better than men. Nonetheless, further research on this issue would be needed to inquire more about the whys and wherefores of this.

\section{Positive Interdependence}

Table 2. Students' Self-Perceived Positive Interdependence

\begin{tabular}{|l|l|r|}
\cline { 2 - 2 } \multicolumn{2}{l|}{} & Percentage \\
\hline Q7. Students who help keep the group working: & Always: & $43.75 \%$ \\
& Sometimes: & $50 \%$ \\
& Almost never: & $6.25 \%$ \\
& Never: & $0 \%$ \\
\hline
\end{tabular}

Note: Information collected with the questionnaire (See Appendix B)

Positive interdependence seems to occur to a moderate extent in the observed group as seen in Table 2, and it may be necessary for the students to receive additional training on it. Still, in the interview, the professor explained to the researcher that one of the greatest advantages of Cooperative Learning is that it creates a certain atmosphere in the classroom. People help each other, and the practice time is increased. Besides, CL allows the use of heterogeneous groups, which contributes to a more balanced learning experience between low and high achievers. 


\section{Individual and Group Accountability}

\begin{tabular}{|c|c|c|}
\hline & & Percentage \\
\hline Q5. Frequency of students' contribution to group work: & $\begin{array}{l}\text { Always: } \\
\text { Sometimes: } \\
\text { Almost never: } \\
\text { Never: }\end{array}$ & $\begin{array}{r}50 \% \\
50 \% \\
0 \% \\
0 \% \\
\end{array}$ \\
\hline
\end{tabular}

Note: Information collected with the questionnaire (See Appendix B)

As shown in Table 3, the students' rating of their individual accountability appears to be rather low. Nonetheless, the professor of the observed group has made a great effort to foster this principle. After reflecting on the information collected during the observations, what at first sight seemed a random way of assigning students to CL groups was actually a carefully planned strategy to produce more satisfactory results in the classroom. For certain activities, student-selected groups work well, yet this may sometimes lead to the formation of cliques in the class, which is definitely not the aim of CL. Thus, when the professor, for instance, assigned the different parts of a reading to be done in the next class, she made sure that groups of friends were given the same part of the reading, so they had to work with classmates other than their friends. The professor also distributed the reading according to its degree of difficulty to low and high achievers. She said, during the interview, that she does this to create heterogeneous groups, a condition that may contribute to a better learning experience since all the students can learn from one another no matter their proficiency level. In fact, this is the second piece of advice given by Jacobs and Hall (1994) when assigning students to Cooperative Learning groups. 


\section{Promotive Interaction}

Table 4. Students' Self-Perceived Promotive interaction

\begin{tabular}{|l|l|r|}
\cline { 3 - 3 } \multicolumn{2}{l|}{} & Percentage \\
\hline group activities: & Always: & $56.25 \%$ \\
& Sometimes: & $43.75 \%$ \\
& Almost never: & $0 \%$ \\
\hline Q12. Students who make sure everyone has a chance & Always: & $37.50 \%$ \\
to talk during group activities: & Sometimes: & $62.5 \%$ \\
& Almost never: & $0 \%$ \\
& Never: & $0 \%$ \\
\hline
\end{tabular}

Note: Information collected with the questionnaire (See Appendix B)

The promotive interaction principle obtained a slightly higher rating by the students in the questionnaire as displayed in Table 4, and it can be stressed that the students may have been provided with sufficient training for this CL principle to occur in the classroom. During the interview, the professor told the researcher that to ensure students' adequate participation in group activities, teaching them communication gambits is very important. She said that one good way to have equal participation is to divide the information necessary for a task among the students so that they learn the importance of interdependence. In this regard, during the observations, the researcher saw that the professor used jigsaw activities several times throughout the course (presumably to serve the purpose mentioned previously). Also, the professor told the researcher that CL proves very useful in oral courses because what is important in these courses is to practice, and it is through practice that a student learns a foreign language. 


\section{Interpersonal and Small Group Skills}

\section{Table 5. Students' Self-Perceived Interpersonal} and Small Group Skills

\begin{tabular}{|l|l|r|}
\cline { 3 - 3 } \multicolumn{2}{l|}{} & Percentage \\
\hline Q8. Students who include everyone in their work: & Always: & $68.75 \%$ \\
& Sometimes: & $31.25 \%$ \\
& Almost never: & $0 \%$ \\
& Never: & $0 \%$ \\
\hline Q9. Students who listen to each other's ideas: & Always: & $43.75 \%$ \\
& Sometimes: & $50 \%$ \\
& Almost never: & $6.25 \%$ \\
& Never: & $0 \%$ \\
\hline
\end{tabular}

Note: Information collected with the questionnaire (See Appendix B)

Table 5 shows that while listening to one another's ideas when working in groups might not be a strong quality in the students, most of them do seem to promote a democratic share of the work. According to the professor during the interview, students must be taught how to take turns, and they have to learn to respect others, to ask for repetition, and not to work with the same classmates all the time. The professor also said that students need to be taught the necessary social skills to work in groups effectively. While doing the observations, the researcher saw that the professor used certain activities that may not have been related to the contents of the course but were likely to serve the aforementioned purpose. In connection with this, experts suggest the use of non-academic activities before implementing Cooperative Learning (Goodwin, 1999; Jensen, Moore, \& Hatch, 2002; Schulte, 1999). Basically, these experts' advice is to make use of these activities on the first day of class. However, the researcher could see during the observations that this kind of activities was used more often, which not only helped the students to work better but also created a very convivial classroom atmosphere. Indeed, these two conditions might deteriorate if they are not encouraged regularly. 


\section{Group Processing}

Table 6. Students' Self-Perceived Group Processing

\begin{tabular}{|l|l|r|}
\cline { 3 - 3 } \multicolumn{2}{l|}{} & Percentage \\
\hline Q10. Students who indicate if an answer or question & Always: & $43.75 \%$ \\
was not understood: & Sometimes: & $50 \%$ \\
& Almost never: & $6.25 \%$ \\
& Never: & $0 \%$ \\
\hline Q11. Students who indicate if someone's idea was good: & Always: & $50 \%$ \\
& Sometimes: & $50 \%$ \\
& Almost never: & $0 \%$ \\
& Never: & $0 \%$ \\
\hline
\end{tabular}

Note: Information collected with the questionnaire (See Appendix B)

Group processing, as seen in Table 6, appears to be low, yet this finding seems to be contradictory when considering what the professor did throughout the course. During the observations conducted, the researcher noticed that for certain group activities, the professor provided her students with assessment instruments such as checklists for them to analyze their performance in them (See Appendix C). After that, the teacher had each group of students discuss the answers marked in the instruments to reflect on their performance and consider ways to improve their work on future occasions.

\section{Students' Assessment of their Experience with Cooperative Learning}

Table 7. Students' Opinion about their Experience with Cooperative Learning

\begin{tabular}{|l|l|r|}
\cline { 2 - 3 } \multicolumn{2}{l|}{} & Percentage \\
\hline Q3. Students' estimation of their learning in the course: & A Lot: & $68.75 \%$ \\
& A little: & $18.75 \%$ \\
& Not much & $12.5 \%$ \\
& Nothing: & $0 \%$ \\
\hline Q4. Students' opinion about the use of group work to & Very useful: & $18.75 \%$ \\
learn English: & Useful: & $68.75 \%$ \\
& Somewhat & $6.25 \%$ \\
& useful: & $6.25 \%$ \\
& Useless: & $0 \%$ \\
\hline
\end{tabular}

Note: Information collected with the questionnaire (See Appendix B) 
Overall, the students' experience with CL in the course can be described as being profitable. Most of them, indeed, said that they learned a lot in the course as seen in Table 7. It is interesting to notice that the students who said they learned a lot were the same that considered group work useful as opposed to very useful. Still, a few students marked the less positive options for this item in the questionnaire. This discrepancy in the obtained responses could indicate that these students may attribute their progress to factors other than group work or CL. This could be related to an interesting detail that was found out during the interview with the professor. She keeps a journal in which she records information about every student in her class. She writes down the progress her students make and also takes notes about what she believes each of her students needs to work on. In fact, she has several pages in her journal devoted to each of her students. She does this in order to provide her students with individualized attention and feedback and to assign her students to groups for certain activities in which she wants the groups to have a fair combination of student performance levels. To sum up, the discrepancy mentioned before may be the result of the individualized attention provided by the professor. What she is doing may go beyond the scope of simple Cooperative Learning. Indeed, this may be related to the advice given by Slavin (2014) when arguing that lessons should not be based entirely on CL; Cooperative Learning may be combined with other resources, techniques, or activities.

\section{Conclusion}

The data gathered for the research indicate that overall the professor of the analyzed group has obtained very good cost-effective results from using CL since most of her students were able to understand and experience the principles of CL to a considerable extent. An important point to bear in mind at this point is that this professor has helped her students reach significant proficiency levels in English by using CL in her class, a finding consistent with that obtained by Gaith (2003). Furthermore, this professor's attitude and commitment to encouraging her students to speak in English constantly and her expertise in using CL have created a positive classroom atmosphere in which the students practice their target language for extended periods of time, the ultimate purpose of a foreign language oral course. 
In light of this, the use of Cooperative Learning strategies and activities in the classroom offers many advantages. Among them, the most remarkable ones are minimizing students' intimidation and fostering their participation in class. In this sense, in teacher-fronted classes, students only have to sit and listen to the teacher lecture them. This type of methodology might make learning experiences dull and monotonous. In addition, this may deter students from asking questions for fear of being ridiculed, and it may not allow students to participate in a course in which oral participation is crucial to achieve the goal of becoming proficient in a foreign language. Cooperative Learning may produce these desired results. Although using CL means working long hours outside the classroom, the results obtained by its implementation are well worth the effort.

\section{Limitations}

At this point of this article, it is important to direct the reader's attention towards some weaknesses identified in the research conducted. First of all, students' attendance was a limitation in the study. This situation was the reason why, when the questionnaire was applied, the information of only $72.73 \%$ of the total number of students in the observed class was obtained. Thus, although the information corresponding to the rest of the students was very relevant and might have affected the results of the study, this loss of information was out of the researcher's control and could not be avoided. In this regard, future researchers could consider designing more comprehensive data collection instruments than the ones used in this research to produce a richer analysis of the occurrence of the principles of Cooperative Learning in a group of students.

Time was also a limiting factor since it restricted the researcher's role during the observations and the collection of data about them. In this regard, it would have been preferable to observe several groups instead of just one, but this could not be done due to the practicality of finding several groups that were working with $\mathrm{CL}$ at the same time. However, if in further studies, this number could be at least two, it would be possible to make comparisons and reach more definite conclusions. 


\section{References}

Dikici, A. \& Yavuzer, Y. (2006). The effects of cooperative learning on the abilities of pre-service art teacher candidates to lesson planning in Turkey. Australian Journal of Teacher Education, 31 (2), 36-44.

Farzaneh, N. \& Nejadansari, D. (2014). Students' attitude towards using cooperative learning for teaching reading comprehension. Theory and Practice in Language Studies, 4 (2), 287-292. doi:10.4304/ tpls.4.2.287-292

Ghaith, G. (2003). Effects of the learning together model of cooperative learning on English as a foreign language reading achievement, academic self-esteem, and feelings of school alienation. Bilingual Research Journal, 27 (3), 451-474.

Goodwin, M. (1999). Cooperative learning and social skills: What to teach and how to teach them. Intervention in School and Clinic, 35 (1), 29-33.

Hernández, A. (2003). Cooperative learning then and now. Repertorio Latinoamericano. Nueva época, 15-16, 299-316.

Hernández, R., Fernández, C., \& Baptista, P. (2006). Metodología de la Investigación (4ta. Ed.). México, D.F: McGraw-Hill Interamericana.

Jacobs, G. \& Hall, S. (1994, October). Implementing cooperative learning. English Teaching Forum, 2-13.

Jensen, M., Moore, R., \& Hatch, J. (2002). Cooperative learningpart 1 cooperative quizzes. The American Biology Teacher, 64 (1), 29-34.

Johnson, D. \& Johnson, R. (2014). Cooperative learning in $21^{\text {st }}$ century. Anales de Psicología, 30 (3), 841-851. Retrieved from http://dx. doi.org/10.6018/analesps.30.3.201241

Johnson, D., Johnson, R., \& Holubec, E. (2008). Cooperation in the classroom. Edina, MN: Interaction Book Company.

Johnson, D., Johnson, R., \& Smith, K. (2007). The state of cooperative learning in postsecondary and professional settings. Educational Psychology Review, 19, 15-29. doi: 10.1007/s10648-006-9038-8

Johnson, D., Johnson, R., \& Smith, K. (1998, July/August). Cooperative learning returns to college: What evidence is there that it works? Change, 27-35. 
Kaufman, D. B., Felder, R. M., Fuller, H. (2000). Accounting for individual effort in cooperative learning teams. Journal of Engineering Education, 89 (2), 133-140.

Leon, L. \& Tai, L. (2004). Implementing cooperative learning in a team-teaching environment. Journal of Education for Business, 79 (5), 287-293.

Mahmoud, M. M. (2014). The effectiveness of using the cooperative language learning approach to enhance EFL writing skills among Saudi university students. Journal of Language Teaching and Research, 5 (3), 616-625. doi:10.4304/j1tr.5.3.616-625

Richards, J. C. \& Farrell, T. S. (2005). Professional development for language teachers: Strategies for teacher learning. New York: Cambridge University Press.

Schulte, P. (1999). Lessons in cooperative learning. Science and Children, $36(7), 44-47$.

Slavin, R. E. (2014, October). Making cooperative learning powerful. Educational Leadership, 22-26.

Summers, J., Beretvas, S., Sviniki, M., Gorin, J. (2005). Evaluating collaborative learning and community. The Journal of Experimental Education, 73 (3), 165-188.

Zhang, Y. (2012). A study on CLL method in reading course. Theory and Practice in Language Studies, 2 (8), 1678-1683. doi:10.4304/ tpls.2.8.1678-1683

Zhang, Y. (2010). Cooperative learning and foreign language learning and teaching. Journal of Language Teaching and Research, 1 (1), 81-83. doi:10.4304/j1tr.1.1.81-83 


\section{Appendix A. Interview Questions for the Professor}

1. How long have you been using CL?

2. When you want to implement $\mathrm{CL}$ in the classroom, what do you need to do first?

3. What social skills do you teach your students so that they can work effectively in CL groups?

4. In what ways is CL different from other kinds of group work?

5. In your opinion, what are the most significant advantages of using CL?

6. What could be some limitations of applying CL?

7. How much time of the class period should be devoted to CL activities?

8. What does a teacher need to use CL effectively? What would be some pieces of advice?

9. How can CL help to teach and learn a foreign language?

\section{Appendix B. Questionnaire for Students}

Date:

Age: Male: Female:

Instructions: Please circle YES or NO or the option that best indicates your level of agreement with each question or statement.

1. Have you done group activities similar to the ones used in this class before?

YES

2. Do you like working in groups?
NO

NO

Why?

\section{YES}

\section{$\longrightarrow$}

3. How much have you learned in this class?
A lot
A little
Not much
Nothing 
4. In learning English, how would you describe working in groups?

Very useful Useful Somewhat useful Useless

5. When working in groups, I try to contribute with my ideas.
Always Sometimes
Almost never
never

6. If I work in a group, I ask others for their ideas and information.
Always
Sometimes
Almost never
never

7. I keep the group working.
Always
Sometimes
Almost never
never

8. We include everyone in our group work.
Always
Sometimes
Almost never
never

9. We listen carefully to each other's ideas.
Always
Sometimes
Almost never
never

10. We say so when we do not understand an answer or question.
Always
Sometimes
Almost never
never

11. We say so when we think someone's ides is good.
Always
Sometimes
Almost never
never

12. We make sure everyone has a chance to talk.
Always
Sometimes
Almost never
never 


\section{Appendix C. Sample Oral Presentation Checklist Provided by the Professor}

\begin{tabular}{|c|c|c|c|}
\hline \multirow[t]{2}{*}{ Name of Presenters } & \multirow[b]{2}{*}{ Points } & \multirow[b]{2}{*}{ Points } & \multirow[b]{2}{*}{ Points } \\
\hline & & & \\
\hline \multicolumn{4}{|l|}{$\begin{array}{l}\text { The presentation was well prepared/ } \\
\text { organized. }\end{array}$} \\
\hline \multicolumn{4}{|l|}{ The speaker gave enough information. } \\
\hline \multicolumn{4}{|l|}{$\begin{array}{l}\text { The speaker used correct pronunciation } \\
\text { and topic-related vocabulary. }\end{array}$} \\
\hline \multicolumn{4}{|l|}{$\begin{array}{l}\text { The speaker used visual aids to convey } \\
\text { meaning. }\end{array}$} \\
\hline \multicolumn{4}{|l|}{ The speaker used eye contact. } \\
\hline \multicolumn{4}{|l|}{$\begin{array}{l}\text { The speaker checked comprehension } \\
\text { after the presentation. }\end{array}$} \\
\hline \multicolumn{4}{|l|}{$\begin{array}{l}\text { Was the student a good listener as } \\
\text { well (ask for clarification, repetition, } \\
\text { explanations)? }\end{array}$} \\
\hline Total number of points & & & \\
\hline
\end{tabular}

Scales:
4. Excellent
3. Very good
2. Good
1. Needs improvement

Comments: 